\title{
Analysis and Sustainable Management of Urban Growth’s Impact on Land Surface Temperature in Lagos, Nigeria
}

Eghosa Igun*

Department of Environmental Management and Toxicology, Western Delta University, Oghara, Nigeria

\begin{abstract}
The rapid growth in urban population is seen to create a need for the development of more urban infrastructures. In order to meet this need, natural surfaces such as vegetation are been replaced with non-vegetated surfaces such as asphalt and bricks which has the ability to absorb heat and release it later. This change in land cover is seen to increase the land surface temperature.

Previous studies have tried to explain the impact of land cover changes on the land surface temperature. However, there is a growing need to spatially quantify the extent to which temperature has increased so as to identify areas where immediate mitigation measures can be applied. In view of this, this study has incorporated remotely sensed Landsat data with remote sensing techniques in order to effectively quantify the spatial extent of urban growth and its impact on the land surface temperature in Lagos, Nigeria.

The result shows that there have been changes in the land cover which has increased the land surface temperature between 2002 and 2013. Overall, there was an increase in the highly dense areas, moderately dense areas and less dense areas by $3.35 \%$ (2200.77 ha), $27.87 \%$ (13681.35 ha), $6.20 \%$ (3284.01 ha) and a corresponding increase in the mean land surface temperature of these urban areas by $3.8^{\circ} \mathrm{C}, 4.2^{\circ} \mathrm{C}$ and $2.2^{\circ} \mathrm{C}$. Hence, it was recommended that in order to reduce the temperature of the urban areas, sustainable urban planning strategies that include increasing the vegetated areas and embracing other green initiatives such as urban forestry should be adopted.
\end{abstract}

Keywords: Enhanced thematic mapper; Land surface temperature; National aeronautics and space administration; Operational land imager; Urban heat island

\section{Introduction}

\section{Background of the study}

It has been projected by the United Nations that by 2050 , over $70 \%$ of the human population will live in urban areas due to the current growth rate of urbanisation [1]. This increase in urbanisation has been putting pressure on the urban areas, such that natural surfaces (such as vegetation, water and soil) are been replaced with man made surfaces (such as buildings, road and tarmac) in order to meet the infrastructural needs of a growing urban population [2,3]. This alteration in land cover is one of the factors that increase the land surface temperature (LST) of the urban environment because man made surfaces absorb and release heat, which contributes to the formation of a phenomenon known as the urban heat island (UHI) $[2,4]$. The UHI refers to a difference in temperature between an urban environment and rural area such that the urban environment is warmer [4].

Although, an explanation of the impact of land cover changes on urban temperature has been well documented by studies such as Oke and Oke et al. [5,6], there are limitations in quantifying the relationship between them [7]. Hence, there is a growing need to carry out research aimed at understanding and quantifying the UHI so as to develop adaptive strategies which will help to diminish its effect [2,7].

\section{Justification of the study}

Lagos is one of the smallest states in Nigeria in terms of landmass, but it has the largest population [8]. Its official population rose from 20,000 in 1850 to 13.4 million in 2000 with a projected increase to 20 million in 2015 [9]. This increase has led to a rapid growth in urbanization as seen in its varying land cover such as built-up area, farmlands and pavements [10]. In view of this varying land cover, it is likely that an UHI would have been formed. The effect of the UHI in Lagos will be enormous considering that Nigeria is already in a hot climatic zone [11]. Also, the electrical demands for cooling buildings with air conditioning are already high and have led to shortages in electrical supply [12]. Therefore, in a hot humid region like Lagos [11], it is important to carry out research aimed at understanding and addressing the issue of urban heat.

Previous study carried out by Oluwamimo [10] to investigate the temporal structure of the UHI in Lagos focused mainly on the use of data collected from ground-based meteorological stations. However, this method is limited in scope because ground-based measurement from meteorological stations does not provide details about the spatial variation of the UHI [6]. Advancement in technology has made it possible to acquire satellite data which provides spatial information of different Earth's surface features using satellite remote sensing techniques [13]. Therefore, the impact of urban growth on the land surface temperature can then be quantified using satellite imagery [7]. The data from ground-based measurements can help to validate the result from the analysis of remotely sensed data [14]. Therefore, combining both data is important in developing a complete understanding of the characteristics of the urban heat.

This study addresses the role that different land cover classes play on the variations in urban temperatures. In particular, it analyses how

*Corresponding author: Eghosa Igun, Department of Environmental Management and Toxicology, Western Delta University, Oghara, Nigeria Tel: 2348082268827; E-mail: igun.eghosa@gmail.com

Received September 12, 2017; Accepted September 26 2017; Published September 28, 2017

Citation: Igun E (2017) Analysis and Sustainable Management of Urban Growth's Impact on Land Surface Temperature in Lagos, Nigeria. J Remote Sensing \& GIS 6: 212. doi: 10.4172/2469-4134.1000212

Copyright: (c) 2017 Igun E. This is an open-access article distributed under the terms of the Creative Commons Attribution License, which permits unrestricted use distribution, and reproduction in any medium, provided the original author and source are credited. 
the loss of natural surfaces have affected the overall surface temperature in Lagos.

\section{Methods and Materials}

\section{Study area}

The study area (Lagos State) is located in the south-western region of Nigeria which is on the coastal flood plain of the Bight of Benin (Figure 1) (Lagos State, 2014). The area lies approximately between longitude $03^{\circ} 24^{\prime} \mathrm{E}$ and latitude $06^{\circ} 25^{\prime} \mathrm{N}$ (Lagos State, 2014). Although it is the smallest State in terms of landmass (3,577 square kilometres), it has one of the highest population of people in Nigeria (17.5 million) (Lagos State, 2014). It is bounded by Ogun State in the north and east, by the Benin Republic in the west and the Atlantic Ocean in the south [8]

Relief and climate of Lagos: Lagos, the seventh fastest growing city in the world, is located in a vegetated tropical zone consisting of the rain forest, mangrove swamp and fresh water swamp [8]. It is a coastal area which consists of estuaries, low lying tidal flats, sandy barriers, islands and wetlands (MOE Lagos, 2014). It is characterised by two seasons; the wet (April to October) and the dry (November to March) [11]. The wet season is characterised by a double peak of rainfall in June and October due to the prevailing south-westerly wind, accompanied by the northward and southward movement of the ITCZ (Inter-tropical Convergence Zone) [11]. The ITCZ is a convergence zone that encourages the development of weather systems which lead to rainfall [15]. In the dry season there is a prevailing north-easterly wind that brings with it the dry dust from the Sahara desert [8]. The mean air temperatures of the wet and dry seasons are $24^{\circ} \mathrm{C}$ and $34^{\circ} \mathrm{C}$ respectively [11]. The rainy season in Benin begins in March/April and ends in October/November. Rainfalls are of high intensity and usually double maxima with a dry little spell in August usually referred to as 'August Break'. Rainfall, temperature, wind and relative humidity are the most significant climatic elements in Benin City. Some cases of temperature extremes between $30^{\circ} \mathrm{C}$ and $35^{\circ} \mathrm{C}$ have been recorded in the city metropolis in November and December.

Meteorological data: The Meteorological data collected from Ikeja Meteorological station covered the period from 1 January 1980 until 31 May 2013. However, they were analysed to cover the period under investigation (2002 to 2013) using Microsoft Excel spreadsheet in order to understand the actual trend in the mean annual temperature for Ikeja.

Satellite data: Some remote sensing techniques were used in this study for quantifying the land cover changes and its influence on the LST, namely, land surface temperature estimation, surface emissivity estimation and land cover classification, accuracy assessment and change detection.

Land surface temperature estimation: The emissivity corrected land surface temperature method which requires the input of emissivity values from different surfaces was used in this study. Firstly, this method entails the conversion of brightness temperature to spectral radiance using equation 1 .

$$
L_{\lambda}=M_{L} Q_{c a l}+A_{L}
$$

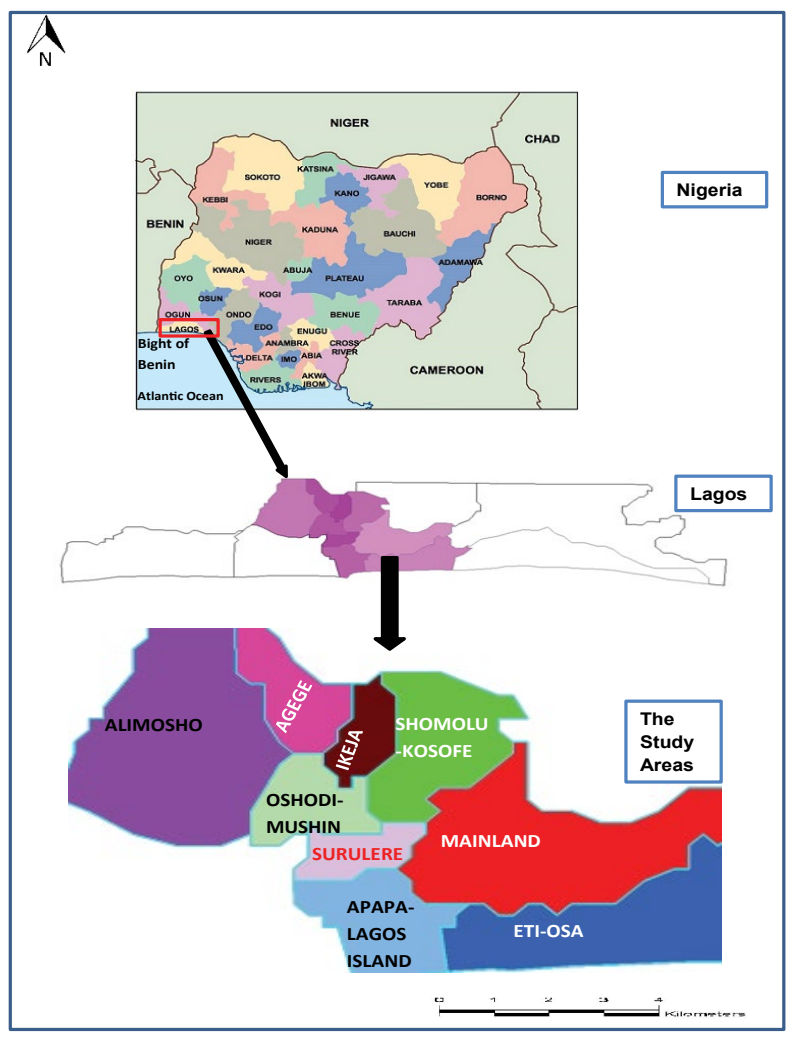

Figure 1: The study area. 
where, $\mathrm{L}_{\lambda}$ is the spectral radiance $\left(\mathrm{W} / \mathrm{m}^{2}\right) ; M_{L}$ is the 'gain' which is 0.067 for Landsat 7 and 0.00033420 for Landsat 8, QCAL is thermal image with units in DN and $A_{L}$ is the 'offset' which is -0.06709 for Landsat 7 and 0.1 for Landsat 8 [16].

Thereafter, the spectral radiance is converted to LST using the Artis and Carnahan [17] equation (equation 2).

$$
\mathrm{T}=\mathrm{K}_{2} / \ln \left(\mathrm{K}_{1} / \mathrm{L}_{\lambda}+1\right)
$$

Where $\mathrm{T}$ is the brightness temperature of the satellite $(\mathrm{K}), \mathrm{L}_{\lambda}$ is the spectral radiance in $\mathrm{W} / \mathrm{m}^{2}$ as calculated in equation 3.1), $\mathrm{K}_{1}$ and $\mathrm{K}_{2}$ are the thermal band conversion constant which are 666.09 and 1282.71 respectively for band 6 and 774.89 and 1321.08 respectively for band 10 .

The values in the temperature values in the LST map were converted from Kelvin $(\mathrm{K})$ to Celsius $\left({ }^{\circ} \mathrm{C}\right)$ (a standard unit of measuring temperature) by subtracting 273 using equation 3 .

$$
\mathrm{T}_{2}=\mathrm{T}_{1}-273
$$

Where $\mathrm{T}_{2}$ is temperature in ${ }^{\circ} \mathrm{C}$ and $\mathrm{T}_{1}$ is temperature in $\mathrm{K}$.

Artis and Carnahan's [17] method requires the input of the surface emissivity values of different Earth's surface features. Hence, Section of Land surface temperature estimation explains the method used in obtaining these surface emissivity values.

Surface emissivity: The surface emissivity of different Earth's surface features can be estimated using two methods; (i) the Normalised Differential Vegetation Index (NDVI) which considers that a pixel in an urban area is made up of either vegetated or soil surface, (ii) the linear mixture model (LMM) which considers that a pixel in urban area is made up of more than one Earth's surface features The LMM was chosen and used in this study because an urban area is made up various surfaces, which increase the likelihood of a pixel having more than one Earth's surface features (such as water, vegetation and soil. In order to use the LMM in estimating the surface emissivity, endmembers were selected to represent the Earth's surface features in the satellite image from pure pixels. These Earth's surface features can be categorised into manmade and non-manmade features [18]. The manmade features from the satellite image were made up of surfaces with high spectral reflectance such as asphalt and tarmac having emissivity values 0.95 and surfaces with low spectral reflectance such as concrete and brick having emissivity value of 0.93 . The non-manmade feature on the other hand was made up of vegetation, soil and water with emissivity values of $0.97,0.96$, and 0.98 respectively. Hence, the LMM (Equation 4) used the following endmembers for this study include (i) high spectral emissivity features (ii) low spectral emissivity feature (iii) water (iv) vegetation and $(\mathrm{v})$ soil.

$$
E=\left(\sum_{i=1}^{n} P_{i} E_{i}\right)
$$

where $\mathrm{E}$ is the surface emissivity, $P_{i}$ is the proportion of the Earth's surface features defined by the various endmembers and $E_{i}$ is the corresponding emissivity of these Earth's surface features.

The result derived from this surface emissivity estimation was used in correcting the LST result estimated from Equation 3.3, in order to assign the various land cover type to their temperature values (Equation 5).

$$
\mathrm{CLST}=\mathrm{T}_{2} \times \mathrm{E}
$$

Where CLST is the corrected land surface temperature $\left({ }^{\circ} \mathrm{C}\right), \mathrm{T}_{2}$ is the temperature converted from $\mathrm{K}$ to Celsius and $\mathrm{E}$ is the surface emissivity (Equation 5).
Land cover classification: There are various method used in carrying out supervised land cover such as the box classifier (parallelepiped), the Minimum Distance to Mean (MDM) and the Maximum likelihood method. However, the maximum likelihood method was chosen because a weighting which helps to minimise errors that may arise due to misclassification can be applied during the classification process. A total of nine land cover types were identified namely; highly dense urban areas, moderately dense urban area, less dense urban area, farmland, densely vegetated area, less dense vegetated area, deep water body and shallow water body. Sample areas known as training sites were then defined in the image in order to represent the various land cover types by various classes.

Change detection: In order to order to observe the rate of increase or decrease in the LST over smaller areas, change detection analysis was also carried out by comparing the LST map for 2002 with that of 2013.

\section{Relationship between land surface temperature and the different land cover types}

In order to show the relationship between the LST and the different land cover types, a statistical approach was used to carry out a correlation and regression analysis. This was done using the percentage proportion of the land cover types and their mean LST for 2002 and 2013 respectively. The percentage proportions of land cover types were classified into vegetated and non-vegetated areas. This is because studies such as Walawender et al. [19] and Connors et al. [20] have shown that classifying the land cover types into vegetated and non-vegetated areas helps in estimating the relationship that exist between the LST and the various land cover types.

\section{Results and Discussion}

\section{Land cover change}

This Section presents the result from the maximum likelihood classification for both the 2002 and 2013 land cover images in order to estimate the land cover changes in the study areas.

The results from the land cover classification presented in Figures $2 \mathrm{a}$ and $2 \mathrm{~b}$. Tables 1 and 2 reveals that there was a general increase in the highly dense urban areas, moderately dense urban areas and less dense urban areas by $3.35 \%$ (2200.77 ha), 27.87\% (13681.35 ha) and $6.20 \%(3284.01 \mathrm{ha})$ respectively across the nine local government areas between 2002 and 2013. This general increase in the urban areas brought about a corresponding decrease in the densely vegetated areas by $48.38 \%$ ( $23778.09 \mathrm{ha})$, farmlands by $0.28 \%$ ( $212.31 \mathrm{ha})$, deep water body by $0.63 \%$ ( $1208.25 \mathrm{ha})$, bare surface by $0.15 \%$ (76.86 ha) and shallow water by $1.06 \%$ (1290.42 ha). There was also an increase in the less dense vegetated area by $10.57 \%$ ( 5203.35 ha). However, there were some notable local government areas which had the highest increase in their highly dense urban areas (Agege), moderately dense urban areas (Alimosho) and less dense urban areas (Eti-Osa) by $22.58 \%(611.01$ ha), $35.96 \%$ ( $8428.86 \mathrm{ha}$ ) and $13.74 \%$ (910.98 ha) respectively between 2002 and 2013. Also, there was an increase in the wetland areas in some local government areas such as Agege, Alimosho, Surulere and Shomolu-Kosefe by $0.01 \%$ ( 0.09 ha), $0.74 \%$ (173.34 ha), 1.63\% (5.13 ha) and $13.31 \%$ ( $996.03 \mathrm{ha}$ ) respectively and a decrease in others such as Apapa-Lagos Island, Eti-Osa, Ikeja, Mainland, and Oshodin-Mushin by $0.28 \%$ (7.92 ha), 5.91\% (402.21 ha), 0.40\% (9.27 ha), 0.60\% (21.69 ha) and $1.21 \%$ (14.49 ha) respectively.

\section{Land surface temperature}

This section presents the results of the LST carried out to evaluate 


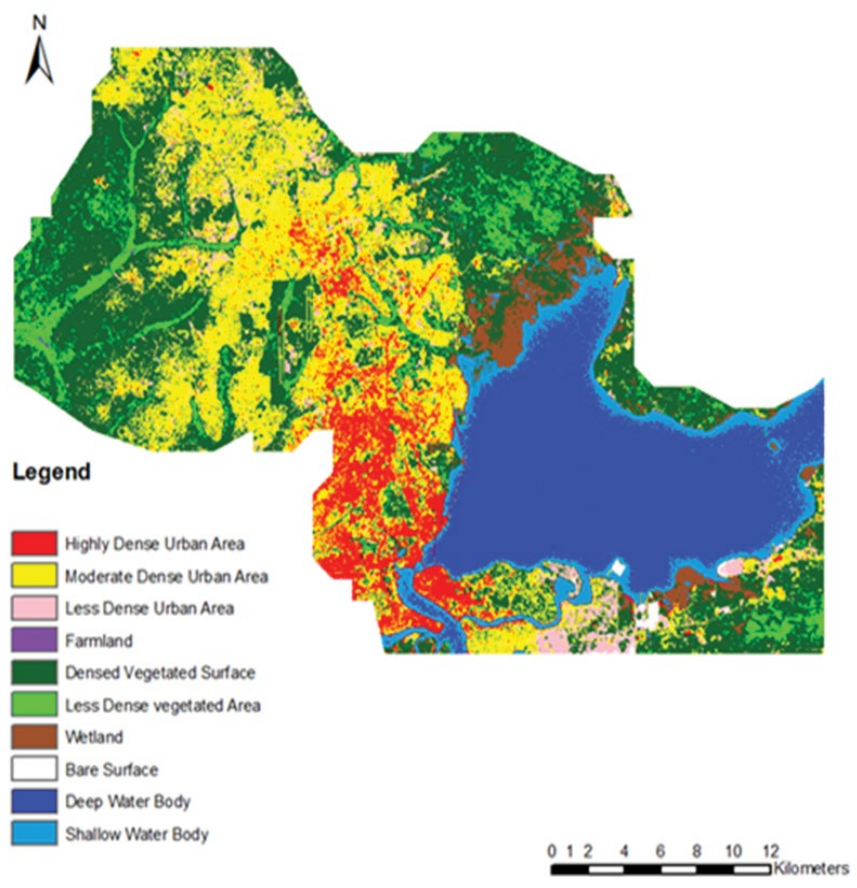

Figure 2a: Land cover classification for the nine local government areas (2002).

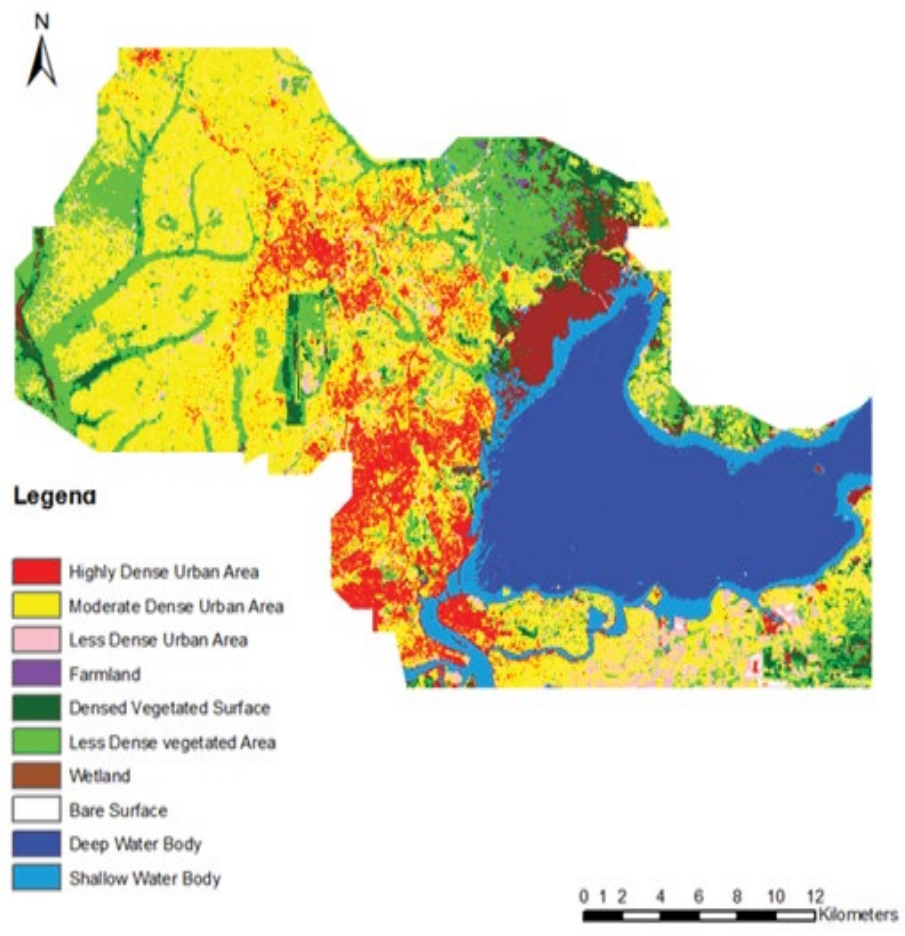

Figure 2b: Land cover classification for the nine local government areas (2013). 
Citation: Igun E (2017) Analysis and Sustainable Management of Urban Growth's Impact on Land Surface Temperature in Lagos, Nigeria. J Remote Sensing \& GIS 6: 212. doi: 10.4172/2469-4134.1000212

Page 5 of 11

\begin{tabular}{|c|c|c|c|c|c|c|c|c|c|c|}
\hline \multirow[b]{2}{*}{$\begin{array}{c}\text { Land } \\
\text { Cover Types }\end{array}$} & \multicolumn{9}{|c|}{ Change in Land Cover types for each Local Government Area between 2002 and 2013} & \multirow{2}{*}{$\begin{array}{l}\text { Total Land Cover } \\
\text { Change for all the } \\
\text { Local Government } \\
\text { Areas (ha) }\end{array}$} \\
\hline & Agege & Alimosho & $\begin{array}{l}\text { Apapa- } \\
\text { Lagos } \\
\text { Island }\end{array}$ & Eti-Osa & Ikeja & Mainland & Surulere & $\begin{array}{l}\text { Oshodi- } \\
\text { Mushin }\end{array}$ & $\begin{array}{l}\text { Shomolu- } \\
\text { Kosefe }\end{array}$ & \\
\hline $\begin{array}{l}\text { Highly Dense Urban } \\
\text { Area }\end{array}$ & 611.01 & 534.60 & 275.58 & 62.64 & 235.62 & 17.91 & 159.21 & 71.64 & 232.56 & 2200.77 \\
\hline $\begin{array}{l}\text { Moderately Dense } \\
\text { Urban Area }\end{array}$ & 548.82 & 8428.86 & 456.93 & 2155.5 & 313.02 & 597.96 & 423.27 & 101.88 & 655.11 & 13681.35 \\
\hline $\begin{array}{l}\text { Less Dense Urban } \\
\text { Area }\end{array}$ & 114.21 & 401.49 & 429.39 & 910.98 & 251.91 & 340.74 & 330.75 & 175.32 & 329.22 & 3284.01 \\
\hline Farmland & 0.72 & 32.58 & Nil & 2.7 & 0.99 & 0.18 & Nil & 0.18 & 174.96 & 212.31 \\
\hline $\begin{array}{l}\text { Densely Vegetated } \\
\text { Area }\end{array}$ & 1238.76 & 11710.08 & 665.46 & 2692.35 & 1165.14 & 1219.23 & 1233.27 & 349.65 & 3504.15 & 23778.09 \\
\hline $\begin{array}{c}\text { Less Dense } \\
\text { Vegetated Area }\end{array}$ & 192.06 & 2155.77 & 108.81 & 263.79 & 366.12 & 388.08 & 323.55 & 94.23 & 1310.94 & 5203.35 \\
\hline Wetland & 0.09 & 173.34 & 7.92 & 402.21 & 9.27 & 21.69 & 5.13 & 14.49 & 996.03 & 1630.17 \\
\hline Bare Surface & 0.90 & 0.00 & 0.09 & 48.42 & 0.54 & 26.46 & 0.27 & 0.18 & 0.2 & 76.86 \\
\hline Deep Water Body & Nil & 0.00 & 503.73 & 189.9 & Nil & 447.39 & Nil & 50.94 & 16.29 & 1208.25 \\
\hline Shallow Water Body & 1.35 & 1.53 & 356.49 & 73.08 & 3.33 & 557.28 & 1.53 & 29.43 & 266.4 & 1290.42 \\
\hline Total Increase (ha) & 2707.92 & 23438.25 & 2804.4 & 6801.57 & 2345.94 & 3616.92 & 2476.98 & 887.94 & 7485.66 & 52565.58 \\
\hline
\end{tabular}

Note: 'Nil' in Table 1 indicates that the land cover type is not in that Local Government Area.

Table 1: Change detection for the various land cover types for all local government areas between 2002 and 2013 (Hectares).

\begin{tabular}{|c|c|c|c|c|c|c|c|c|c|c|}
\hline \multirow[b]{2}{*}{$\begin{array}{l}\text { Land } \\
\text { Cover Types }\end{array}$} & \multicolumn{9}{|c|}{ Percentage Change in Land Cover Types for each Local Government Area Between 2002 and 2013} & \multirow{2}{*}{$\begin{array}{l}\text { Average \% Land } \\
\text { Cover Change } \\
\text { for all the Local } \\
\text { Government } \\
\text { Areas }\end{array}$} \\
\hline & Agege & Alimosho & $\begin{array}{l}\text { Apapa- } \\
\text { Lagos } \\
\text { Island }\end{array}$ & Eti-Osa & Ikeja & Mainland & Surulere & $\begin{array}{l}\text { Oshodi- } \\
\text { Mushin }\end{array}$ & $\begin{array}{l}\text { Shomolu- } \\
\text { Kosefe }\end{array}$ & \\
\hline $\begin{array}{l}\text { Highly Dense Urban } \\
\text { Area }\end{array}$ & $\begin{array}{l}22.56 \% \\
\text { Increase }\end{array}$ & $\begin{array}{l}2.28 \% \\
\text { Increase }\end{array}$ & $\begin{array}{l}9.83 \% \\
\text { Increase }\end{array}$ & $\begin{array}{c}0.92 \% \\
\text { Increase }\end{array}$ & $\begin{array}{l}10.04 \% \\
\text { Increase }\end{array}$ & $\begin{array}{c}0.50 \% \\
\text { Increase }\end{array}$ & $\begin{array}{l}8.07 \% \\
\text { Increase }\end{array}$ & $\begin{array}{c}6.43 \% \\
\text { Increase }\end{array}$ & $\begin{array}{l}3.11 \% \\
\text { Increase }\end{array}$ & $3.35 \%$ Increase \\
\hline $\begin{array}{l}\text { Moderately Dense } \\
\text { Urban Area }\end{array}$ & $\begin{array}{l}20.27 \% \\
\text { Increase }\end{array}$ & $\begin{array}{l}35.96 \% \\
\text { Increase }\end{array}$ & $\begin{array}{l}16.29 \% \\
\text { Increase }\end{array}$ & $\begin{array}{l}31.69 \% \\
\text { Increase }\end{array}$ & $\begin{array}{l}13.34 \% \\
\text { Increase }\end{array}$ & $\begin{array}{l}16.53 \% \\
\text { Increase }\end{array}$ & $\begin{array}{l}11.47 \% \\
\text { Increase }\end{array}$ & $\begin{array}{l}17.09 \% \\
\text { Increase }\end{array}$ & $\begin{array}{l}8.75 \% \\
\text { Increase }\end{array}$ & $27.87 \%$ Increase \\
\hline $\begin{array}{c}\text { Less Dense Urban } \\
\text { Area }\end{array}$ & $\begin{array}{l}4.22 \% \\
\text { Increase }\end{array}$ & $\begin{array}{l}1.71 \% \\
\text { Increase }\end{array}$ & $\begin{array}{l}15.31 \% \\
\text { Increase }\end{array}$ & $\begin{array}{l}13.39 \% \\
\text { Increase }\end{array}$ & $\begin{array}{l}10.74 \% \\
\text { Increase }\end{array}$ & $\begin{array}{l}9.42 \% \\
\text { Increase }\end{array}$ & $\begin{array}{l}19.74 \% \\
\text { Increase }\end{array}$ & $\begin{array}{l}13.35 \% \\
\text { Increase }\end{array}$ & $\begin{array}{l}4.40 \% \\
\text { Increase }\end{array}$ & $6.20 \%$ Increase \\
\hline Farmland & $\begin{array}{c}0.03 \% \\
\text { Decrease }\end{array}$ & $\begin{array}{l}0.14 \% \% \\
\text { Decrease }\end{array}$ & Nil & $\begin{array}{l}0.04 \% \\
\text { Decrease }\end{array}$ & $\begin{array}{l}0.04 \% \\
\text { Decrease }\end{array}$ & $\begin{array}{c}0.2 \% \\
\text { Decrease }\end{array}$ & $\begin{array}{l}0.02 \% \\
\text { Decrease }\end{array}$ & Nil & $\begin{array}{l}0.34 \% \\
\text { Decrease }\end{array}$ & $0.28 \%$ Decrease \\
\hline $\begin{array}{l}\text { Densely Vegetated } \\
\text { Area }\end{array}$ & $\begin{array}{l}45.75 \% \\
\text { Decrease }\end{array}$ & $\begin{array}{l}49.96 \% \\
\text { Decrease }\end{array}$ & $\begin{array}{l}23.73 \% \\
\text { Decrease }\end{array}$ & $\begin{array}{l}39.58 \% \\
\text { Decrease }\end{array}$ & $\begin{array}{l}49.67 \% \\
\text { Decrease }\end{array}$ & $\begin{array}{l}33.71 \% \\
\text { Decrease }\end{array}$ & $\begin{array}{l}39.38 \% \\
\text { Decrease }\end{array}$ & $\begin{array}{l}49.79 \% \\
\text { Decrease }\end{array}$ & $\begin{array}{l}46.81 \% \\
\text { Decrease }\end{array}$ & $\begin{array}{l}48.38 \% \\
\text { Decrease }\end{array}$ \\
\hline $\begin{array}{c}\text { Less Dense Vegetated } \\
\text { Area }\end{array}$ & $\begin{array}{l}7.09 \% \\
\text { Increase }\end{array}$ & $\begin{array}{l}9.20 \% \\
\text { Increase }\end{array}$ & $\begin{array}{c}3.88 \% \\
\text { Increase }\end{array}$ & $\begin{array}{c}3.88 \% \\
\text { Increase }\end{array}$ & $\begin{array}{l}15.61 \% \\
\text { Increase }\end{array}$ & $\begin{array}{l}10.73 \% \\
\text { Increase }\end{array}$ & $\begin{array}{c}10.61 \% \\
\text { Increase }\end{array}$ & $\begin{array}{l}13.06 \% \\
\text { Increase }\end{array}$ & $\begin{array}{l}17.51 \% \\
\text { Increase }\end{array}$ & $10.57 \%$ Increase \\
\hline Wetland & $\begin{array}{c}0.01 \% \\
\text { Increase }\end{array}$ & $\begin{array}{c}0.74 \% \\
\text { Increase }\end{array}$ & $\begin{array}{c}0.28 \% \\
\text { Decrease }\end{array}$ & $\begin{array}{c}5.91 \% \\
\text { Decrease }\end{array}$ & $\begin{array}{c}0.40 \% \\
\text { Decrease }\end{array}$ & $\begin{array}{c}0.60 \% \\
\text { Decrease }\end{array}$ & $\begin{array}{c}1.63 \% \\
\text { Increase }\end{array}$ & $\begin{array}{c}0.21 \% \\
\text { Decrease }\end{array}$ & $\begin{array}{l}13.31 \% \\
\text { Increase }\end{array}$ & $1.50 \%$ Increase \\
\hline Bare Surface & $\begin{array}{c}0.03 \% \\
\text { Decrease }\end{array}$ & $\begin{array}{c}0.01 \% \\
\text { Decrease }\end{array}$ & $\begin{array}{c}0.01 \% \\
\text { Decrease }\end{array}$ & $\begin{array}{c}0.71 \% \\
\text { Decrease }\end{array}$ & $\begin{array}{c}0.02 \% \\
\text { Decrease }\end{array}$ & $\begin{array}{c}0.73 \% \\
\text { Decrease }\end{array}$ & $\begin{array}{c}0.02 \% \\
\text { Decrease }\end{array}$ & $\begin{array}{c}0.01 \% \\
\text { Decrease }\end{array}$ & $\begin{array}{c}0.01 \% \\
\text { Decrease }\end{array}$ & $0.15 \%$ Decrease \\
\hline Deep Water Body & Nil & Nil & $\begin{array}{c}17.96 \% \\
\text { Decrease }\end{array}$ & $\begin{array}{c}2.79 \% \\
\text { Decrease }\end{array}$ & Nil & $\begin{array}{l}12.37 \% \\
\text { Increase }\end{array}$ & $\begin{array}{c}5.74 \% \\
\text { Decrease }\end{array}$ & Nil & $\begin{array}{c}0.22 \% \\
\text { Decrease }\end{array}$ & $0.63 \%$ Decrease \\
\hline Shallow Water Body & $\begin{array}{c}0.05 \% \\
\text { Decrease }\end{array}$ & $\begin{array}{c}0.01 \% \\
\text { Decrease }\end{array}$ & $\begin{array}{c}12.71 \% \\
\text { Decrease }\end{array}$ & $\begin{array}{c}1.07 \% \\
\text { Decrease }\end{array}$ & $\begin{array}{c}0.14 \% \\
\text { Decrease }\end{array}$ & $\begin{array}{c}15.41 \% \\
\text { Decrease }\end{array}$ & $\begin{array}{c}3.31 \% \\
\text { Decrease }\end{array}$ & $\begin{array}{c}0.06 \% \\
\text { Decrease }\end{array}$ & $\begin{array}{c}3.56 \% \\
\text { Decrease }\end{array}$ & $1.06 \%$ Decrease \\
\hline Total Change (\%) & 100 & 100 & 100 & 100 & 100 & 100 & 100 & 100 & 100 & 100 \\
\hline
\end{tabular}

Note: 'Nil' in Table 2 indicates that the land cover type is not in that Local Government Area.

Table 2: Change detection for the various land cover types between 2002 and 2013 (Percentage).

the changes in the surface temperature in the study area between 2002 and 2013. The result of the LST are presented in Figures $3 \mathrm{a}$ and $2 \mathrm{~b}$. Also, Table 3 shows the result of the maximum and minimum LST for all local government areas. The results presented in Figure $3 \mathrm{a}$ and $3 \mathrm{~b}$. Table 3 indicate that the maximum and minimum LST increased across all nine local government areas between 2002 and 2013. The highest increase in the maximum LST $\left(6^{\circ} \mathrm{C}\right)$ was seen in Shomolu-Kosefe, 
Citation: Igun E (2017) Analysis and Sustainable Management of Urban Growth's Impact on Land Surface Temperature in Lagos, Nigeria. J Remote Sensing \& GIS 6: 212. doi: 10.4172/2469-4134.1000212

while the highest increase in the minimum LST $\left(6^{\circ} \mathrm{C}\right)$ was noticed in Agege. Also, result in Table 4 shows that the highest mean temperature of $26.64^{\circ} \mathrm{C}$ and $32.30^{\circ} \mathrm{C}$ with standard deviation of 1.39 and 1.59 were observed for 2002 and 2013 respectively in Agege. The lowest mean LST was observed in mainland having $21.35^{\circ} \mathrm{C}$ and $24.78^{\circ} \mathrm{C}$ with standard deviation of 1.16 and 1.32 respectively.

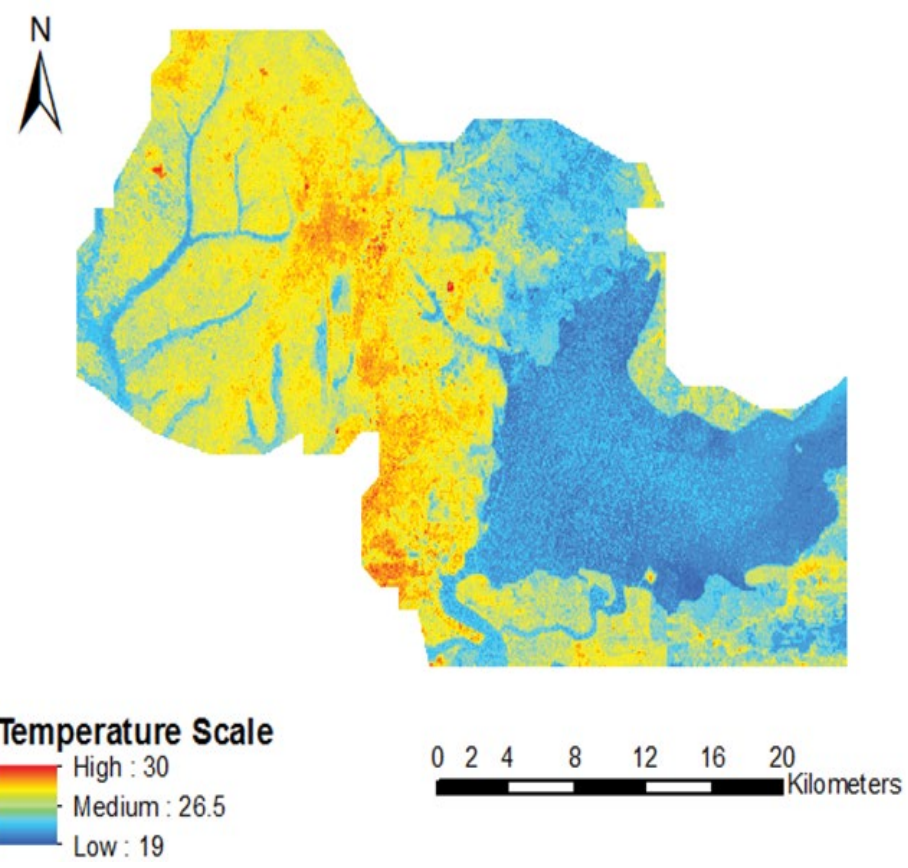

Figure 3a: Land surface temperature map for all local government areas (2002).

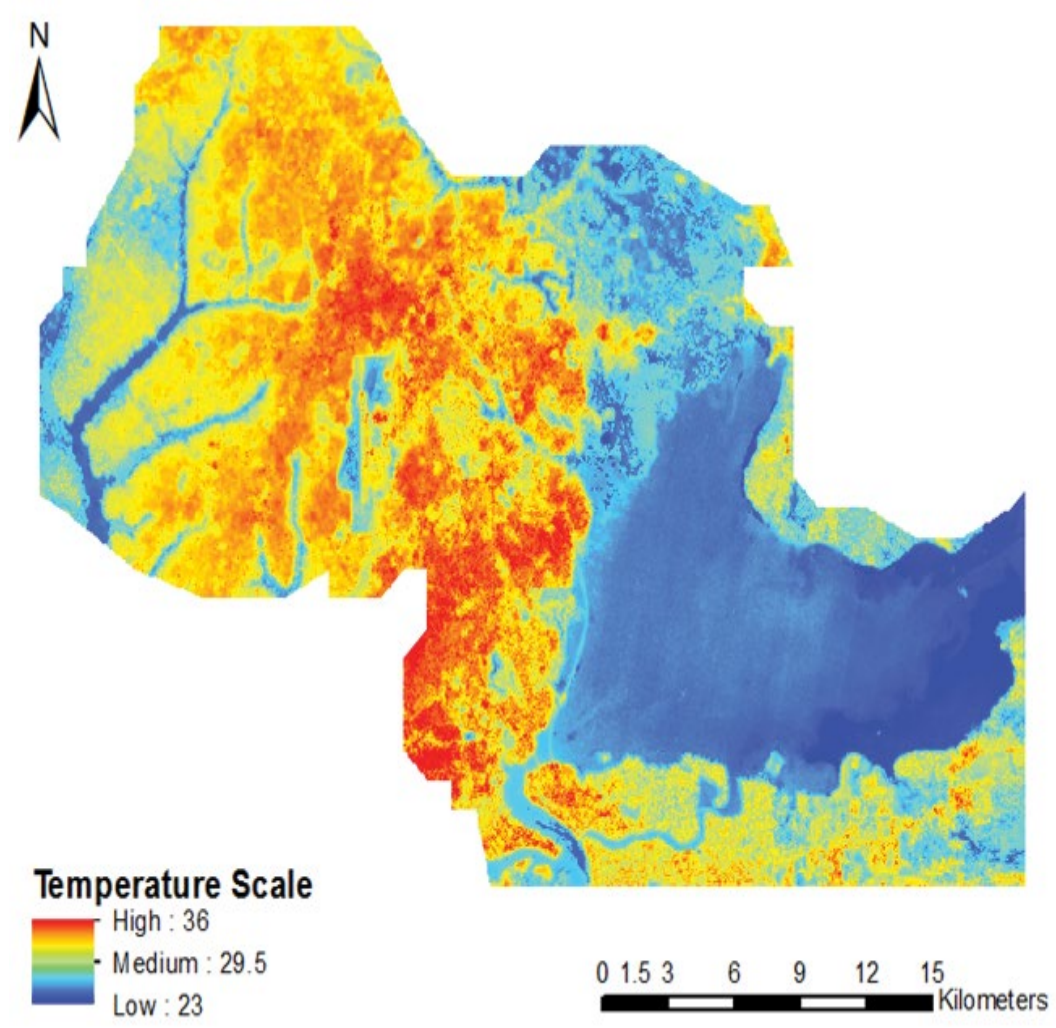

Figure 3b: Land surface temperature map for all local government areas (2013). 


\section{Change detection for the land surface temperature}

The result of the change detection carried out in order to understand for the change in LST between 2002 and 2013 is shown in Figure 4.

The LST map presented in Figure 4 reveals that one-third of the study area has remained unchanged (i.e., areas that have similar temperature both in 2002 and 2013). Also, one third of the area has experience an increase of $2^{\circ} \mathrm{C}$ in the LST from 2002 to 2013, while the remaining one-third shows areas where the LST has either decrease by $2^{\circ} \mathrm{C}$ of increase by $4^{\circ} \mathrm{C}$ and $6^{\circ} \mathrm{C}$ respectively. An assessment of these areas was done using prior knowledge of the study area, Google Earth maps and the classified land cover maps for 2002 and 2013 (Figures $2 \mathrm{a}$ and $2 \mathrm{~b}$ ) in order to get a better understanding of these changes. It was discovered that the area where LST has decrease by $2^{\circ} \mathrm{C}$ is a state owned reserved vegetated area in Alimosho. The areas where LST has remained unchanged or has increase by $2^{\circ} \mathrm{C}$ are areas that are either occupied by water bodies or still vegetated. Also, the areas with $4^{\circ} \mathrm{C}$ and $6^{\circ} \mathrm{C}$ increase in the LST were vegetated in 2002 but have had their surfaces changed. For instance, it was discovered that in Alimosho, there was a newly built estate area, while in Apapa-Victoria Island there was a newly established industrial area, in Ikeja airport a new constructed tarmac and in Eti-Osa a densely urban area has emerged. This increase in temperature is a pointer to the change in the spatial pattern of the LST in Lagos.

\section{Relationship between the land surface temperature and the land cover type}

This section presents the results of the correlation and regression between the land cover types (vegetated and non-vegetated surfaces) and the LST as explained in Section. This was done using the mean value of the LST for 2002 and 2013 and the corresponding percentage proportion of vegetation and non-vegetated areas in order to understand the relationship that exist between the land cover type and the LST. Figures $5 \mathrm{a}$ and $6 \mathrm{a}$ show the result of the LST and the proportion of vegetated areas (2002 and 2013), while Figures $5 \mathrm{~b}$ and $6 \mathrm{~b}$ shows the result of the LST and the proportion of non-vegetated areas (2002 and 2013).
The results in Figures 5a and 6a shows that there is a strong negative correlation between the mean LST and the percentage proportion of the vegetated areas of all the nine Local Government areas in 2002 and 2013. This means that as the proportion of vegetated surfaces increases, the mean LST decreases. These results were found to be highly significant at $\mathrm{P}<0.0001$. In contrast, Figures $5 \mathrm{~b}$ and $6 \mathrm{~b}$ show that there is a strong positive correlation between the mean LST and percentage proportion of non-vegetated areas such that as the mean LST increases, the percentage proportion of non-vegetated areas increases. The results were also highly significant at $\mathrm{P}<0.0001$.

\section{Mean maximum and minimum temperature}

In order to know if there has been this increase in the LST the study area, an analysis of the trend in the mean annual maximum and minimum temperature of a meteorological station (Ikeja Station) was carried out as shown in Figures 6a and 6b.

The results in Figures $6 \mathrm{a}$ and $6 \mathrm{~b}$ show that there has been an increase in the trend of the mean annual maximum and minimum temperature from 2002 to 2013 in Ikeja. Also, the mean annual minimum temperature is seen to be increasing by $0.04^{\circ} \mathrm{C}$ per year, while the mean annual maximum temperature was observed to be increasing by $0.05^{\circ} \mathrm{C}$ per year. However, there were variations in the minimum and maximum temperature of some years which according to a study carried out by Akinsanola and Ogunjobi [21] was due to prolonged dry or wet seasons likely caused by climate change.

From the findings of this study, the following can be inferred. Firstly, thermal Landsat imagery was seen to be suitable in characterising the LST as (Section of Land surface temperature) noted in studies such as Schubring et al., Hancock et al., Javed et al., Tan et al. and Nichol and Wong [7,22-25]. Secondly, it is evident that most of the densely vegetated areas present in 2002 have been cleared in order to give way for more urban structures (such as buildings and roads) between 2002 and 2013 (Section of Land cover change). Also, the decrease in the shallow and

\begin{tabular}{|c|c|c|c|c|c|c|}
\hline $\begin{array}{c}\text { Local Government } \\
\text { Areas }\end{array}$ & $\begin{array}{c}2002 \text { Maximum LST } \\
\left({ }^{\circ} \mathrm{C}\right)\end{array}$ & $\begin{array}{l}2013 \text { Maximum LST } \\
\left({ }^{\circ} \mathrm{C}\right)\end{array}$ & Difference $\left({ }^{\circ} \mathrm{C}\right)$ & $\begin{array}{c}2002 \text { Minimum LST } \\
\left({ }^{\circ} \mathrm{C}\right)\end{array}$ & $\begin{array}{c}2013 \text { Minimum LST } \\
\left({ }^{\circ} \mathrm{C}\right)\end{array}$ & $\begin{array}{l}\text { Difference } \\
\quad\left({ }^{\circ} \mathrm{C}\right)\end{array}$ \\
\hline Agege & 31 & 36 & 5 & 19 & 25 & 6 \\
\hline Alimosho & 34 & 35 & 1 & 20 & 24 & 4 \\
\hline Apapa-Lagos Island & 31 & 36 & 5 & 19 & 24 & 5 \\
\hline Eti-Osa & 29 & 33 & 4 & 19 & 23 & 4 \\
\hline Ikeja & 33 & 35 & 2 & 20 & 25 & 5 \\
\hline Mainland & 28 & 33 & 5 & 19 & 23 & 4 \\
\hline Oshodi-Mushin & 30 & 35 & 5 & 20 & 25 & 5 \\
\hline Shomolu-Kosofe & 29 & 35 & 6 & 19 & 24 & 5 \\
\hline Surulere & 31 & 35 & 4 & 19 & 24 & 5 \\
\hline
\end{tabular}

Table 3: The maximum and minimum land surface temperature for each local government area (2002 and 2013).

\begin{tabular}{|c|c|c|c|c|}
\hline Local Government Areas & 2002 Mean LST $\left({ }^{\circ} \mathrm{C}\right)$ & $\begin{array}{l}\text { Standard } \\
\text { Deviation }\end{array}$ & 2013 Mean LST $\left({ }^{\circ} \mathrm{C}\right)$ & Standard Deviation \\
\hline Agege & 26.65 & 1.39 & 32.30 & 1.54 \\
\hline Alimosho & 25.39 & 1.72 & 30.87 & 2.30 \\
\hline Apapa-Lagos Island & 24.82 & 2.51 & 29.67 & 3.09 \\
\hline Eti-Osa & 23.55 & 1.95 & 28.29 & 2.04 \\
\hline Ikeja & 25.13 & 1.99 & 30.78 & 2.37 \\
\hline Mainland & 21.35 & 1.16 & 24.78 & 1.32 \\
\hline Oshodi-Mushin & 26.56 & 1.50 & 32.01 & 1.77 \\
\hline Shomolu-Kosofe & 22.48 & 1.78 & 27.29 & 2.46 \\
\hline Surulere & 25.78 & 2.63 & 31.12 & 3.37 \\
\hline
\end{tabular}

Table 4: The mean LST for each of the local government areas (2002 and 2013). 

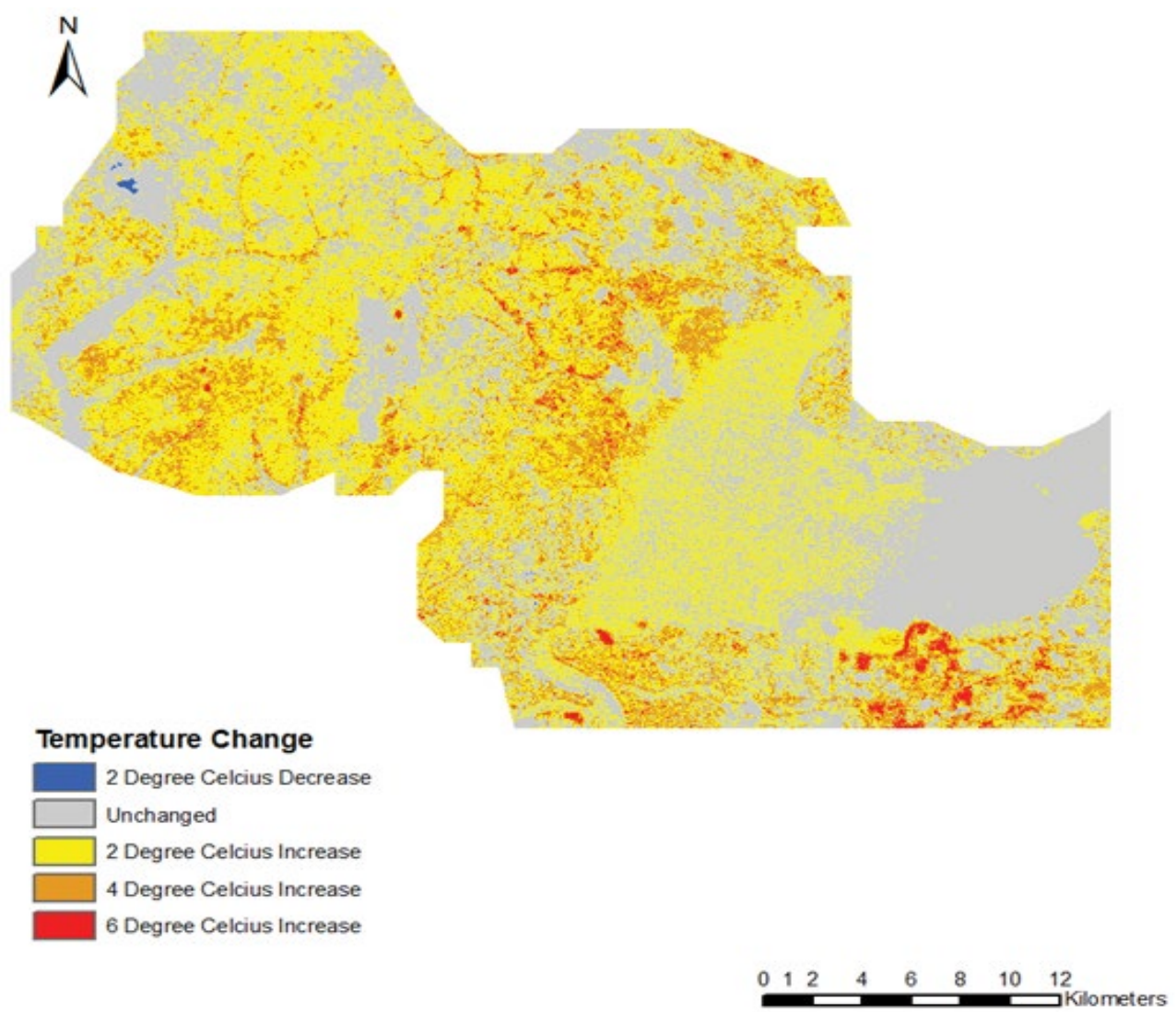

Figure 4: Change in LST between 2002 and 2013.

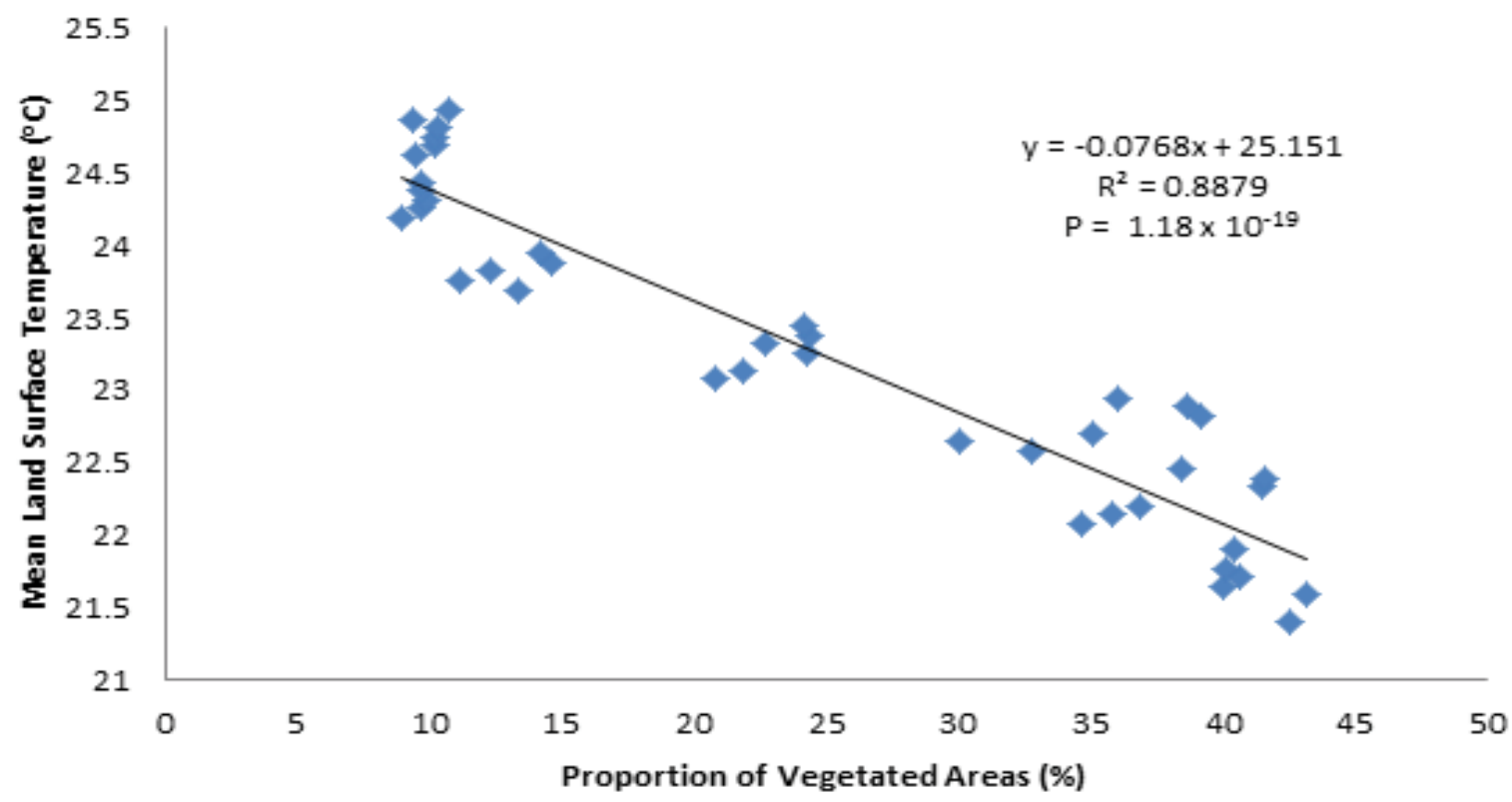

Figure 5a: The correlation of the mean LST and the percentage proportion of the vegetated surface (2002). 


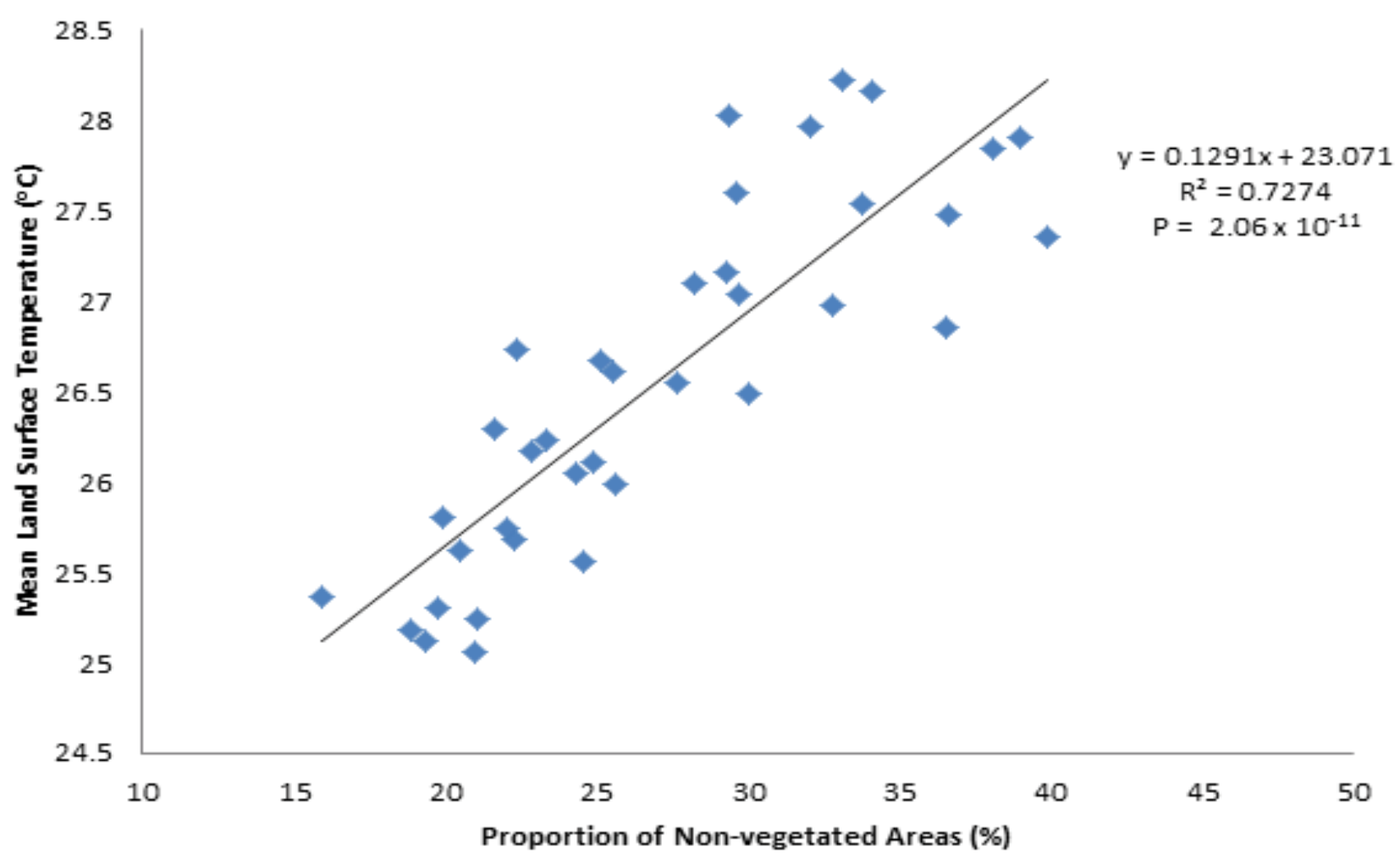

Figure 5b: The correlation of the mean LST and the percentage proportion of the non-vegetated area (2002).

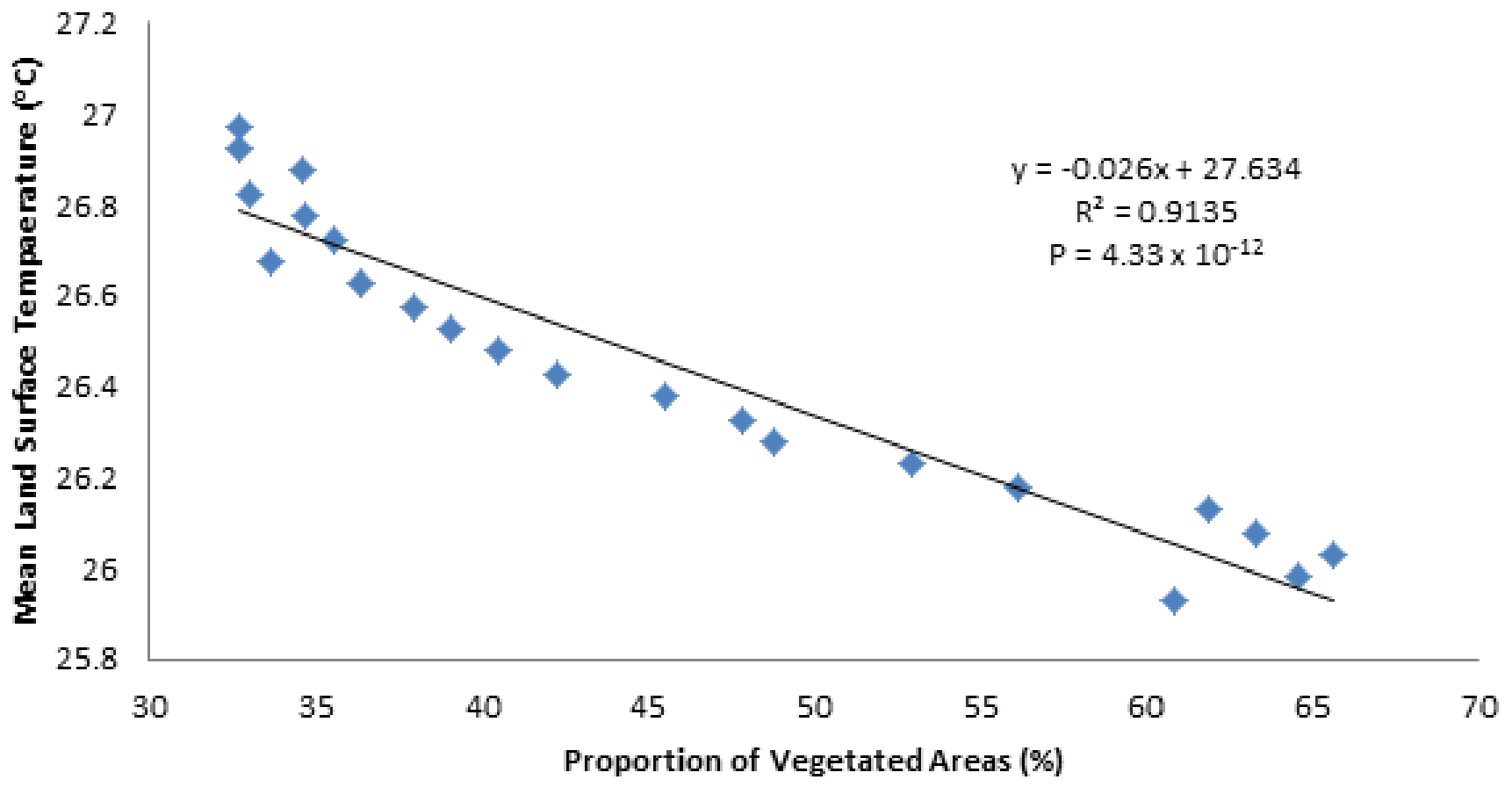

Figure 6a: The correlation of the mean LST and the percentage proportion of the vegetated areas (2013). 


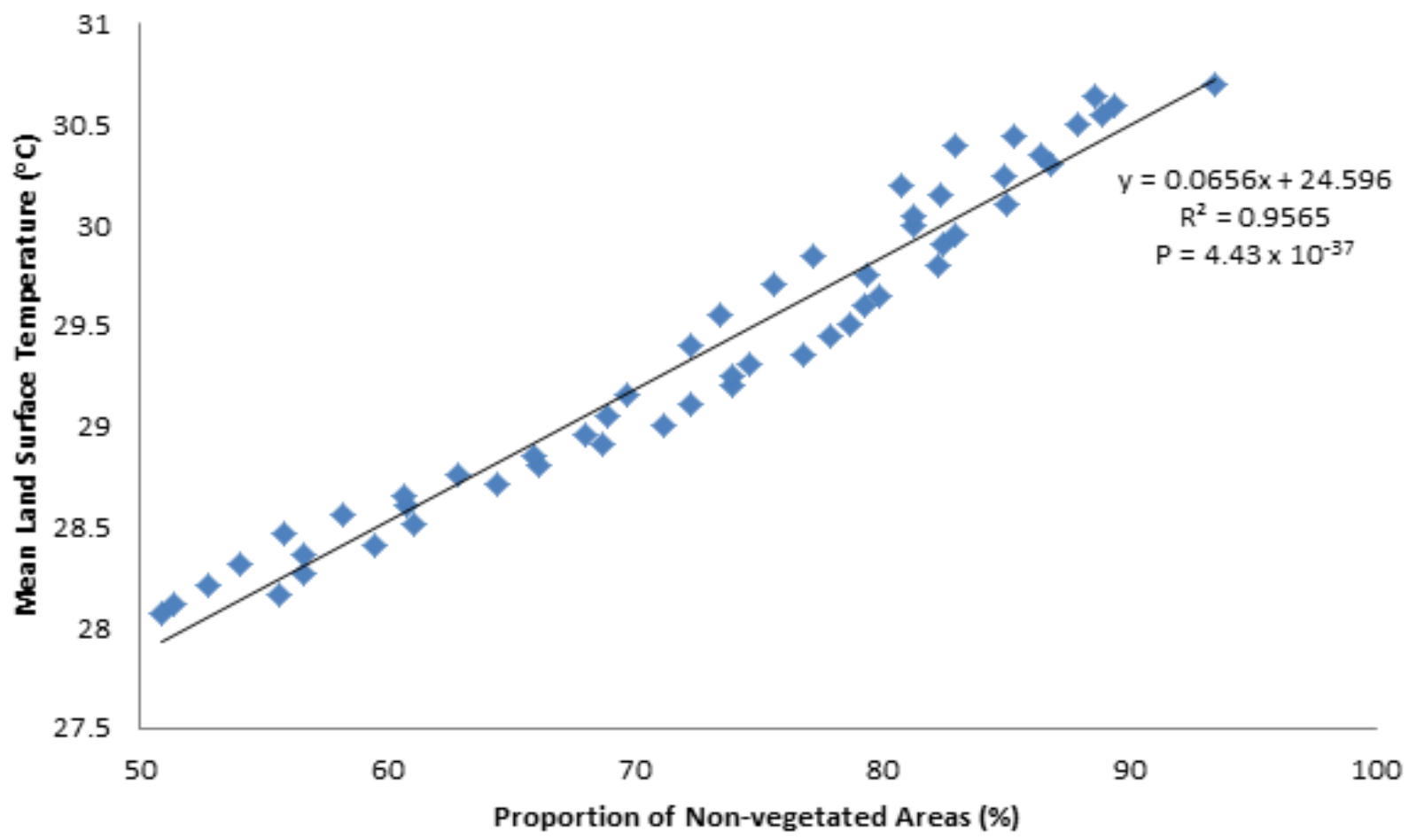

Figure 6b: The Correlation of the mean LST and the percentage proportion of the non-vegetated areas (2013).

deep-water bodies indicates that the urban areas are also spreading towards the lagoon in the Mainland local government area. Thirdly, it is apparent that the increase in LST (Section of Land surface temperature) is as a result of the increase in various manmade features (such as bricks and asphalt) that can absorb heat and release it later to warm their surrounding environment. Also, this increase in temperature has modified the urban climate such that the spatial profile between 2002 and 2013 differs (see Section of Relationship between the land surface temperature and the land cover type). Fourthly, the fact that the spatial pattern of the LST differs from the classical spatial pattern (see Section of Relationship between the land surface temperature and the land cover type) indicates that there is no central city in Lagos. This is because there are various urbanised areas with different peak temperatures. In view of this, it is likely that the UHI effect is being felt in almost all builtup areas and not restricted to a particular region. Fifthly, the results of the correlation and regression show that the non-vegetated areas have a positive influence on the increasing temperatures in urban areas. These observations are consistent with Schubring et al., Xian and Crane, Zhao et al. and Connors et al. [7,20,26,27] who observed that non-vegetated areas have an impact in increasing the LST of urban areas. Sixthly, the areas identified and classified as hotspots having temperatures between 4 and $6^{\circ} \mathrm{C}$ (see Section of Relationship between the land surface temperature and the land cover type), were seen to be newly developed areas. Hence, there is a need for the government and the local planers in Lagos to incorporate the idea of environmental sustainability into their urban planning strategies.

\section{Conclusion}

Human exploitation of the natural environment through urban development has a major impact on the urban climate at a global scale. One major phenomenon that arises as a result of this exploitation is the increase in land surface temperature. This study was aimed at evaluating the nature of such exploitation of the natural environment on the overall increase in the land surface temperature of Lagos, Nigeria.

The results from the analysis showed that there have been changes in the different land cover types due to urban growth. This growth has affected the LST of the study area in varying degrees. Hence, in order to mitigate these impacts, sustainability planning methods that include green and cool roofs, urban forestry and increased vegetated surfaces in urban areas which is currently lacking should be introduced.

\section{References}

1. UN (2007) World urbanization prospects: The 2007 revision of population database.

2. Gill SE, Handley JF, Ennos AR, Pauleit S (2007) Adapting cities for climate change: the role of the green infrastructure. Built Environment 33: 115-133.

3. Fortuniak K (2009) Global environmental change and urban climate in Central European cities.

4. Oke TR (1973) City size and the urban heat island. Atmospheric Environment 7: 769-779.

5. Oke TR (1981) Canyon geometry and the nocturnal urban heat island: comparison of scale model and field observations. International Journal of Climatology 1: 237-254.

6. Oke TR, Johnson GT, Steyn DG, Watson ID (1991) Simulation of surface urban heat islands under 'ideal'conditions at night Part 2: Diagnosis of causation. Boundary-Layer Meteorology 56: 339-358.

7. Weng Q, Lu D, Schubring J (2004) Estimation of land surface temperaturevegetation abundance relationship for urban heat island studies. Remote sensing of Environment 89: 467-483.

8. MOE Lagos (2014) Lagos state ministry of the environment.

9. Lagos State MEPB (2014) A report by the Lagos State Ministry of economic planning and budget in collaboration with the Lagos State Ministry of physical planning and urban development. 
Citation: Igun E (2017) Analysis and Sustainable Management of Urban Growth's Impact on Land Surface Temperature in Lagos, Nigeria. J Remote Sensing \& GIS 6: 212. doi: 10.4172/2469-4134.1000212

Page 11 of 11

10. Oluwamimo S (2006) The temporal structure of the urban heat island in Lagos, Nigeria. European Geosciences Union 45: 1-12.

11. NIMET (2012) Nigeria Climate Review Bulletin 2012.

12. NERC (2014) Nigerian Electricity Regulatory Commission.

13. Tarolli $P$, Arrowsmith JR, Vivoni ER (2009) Understanding earth surface processes from remotely sensed digital terrain models. Geomorphology 113: 1-3.

14. Justice C, Belward A, Morisette J, Lewis P, Privette J, et al. (2000) Developments in the validation of satellite sensor products for the study of the land surface. International Journal of Remote Sensing 21: 3383-3390.

15. NASA (2007) Landsat science data user's handbook.

16. WMO (2014) Significant natural climate fluctuations.

17. Artis DA, Carnahan WH (1982) Survey of emissivity variability in thermography of urban areas. Remote Sensing of Environment 12: 313-329.

18. Song $\mathrm{CH}$ (2005) Spectral mixture analysis for sub pixel fractions in the urban environment: how to incorporate endmembers variability. Remote Sensing of Environment 95: 248-263.

19. Walawender JP, Szymanowski M, Hajto MJ, Bokwa A (2014) Land surface temperature patterns in the urban agglomeration of Krakow (Poland) derived from Landsat-7/ETM+ data. Pure and Applied Geophysics 171: 913-940.

20. Connors JP, Galletti CS, Chow WT (2013) Landscape configuration and urban heat island effects: assessing the relationship between landscape characteristics and land surface temperature in Phoenix, Arizona. Landscape Ecology 28: 271-283.

21. Akinsanola AA, Ogunjobi KO (2014) Analysis of rainfall and temperature variability over Nigeria. Global Journal of Human Social Science 14: 3-5.

22. Hancock RN, Gillespie AR, Cherkauer KA, Kay JE, Burges SJ, et al. (2006) Accuracy and uncertainty of thermal infrared remote sensing of stream temperatures at multiple spatial scales. Remote Sensing of Environment 100 : 427-440.

23. Javed M, Yogesh K, Bharath BD (2008) Estimation of land surface temperature over Delhi using Landsat-7 ETM+. Journal of Industrial Geophysics 12: 131-140.

24. Tan KC, San Lim H, MatJafri MZ, Abdullah K (2010) Landsat data to evaluate urban expansion and determine land use/land cover changes in Penang Island, Malaysia. Environmental Earth Sciences 60: 1509-1521.

25. Wong MS, Nichol JE (2013) Spatial variability of frontal area index and its relationship with urban heat island intensity. International Journal of Remote Sensing 34: 885-896.

26. Xian G, Crane M (2006) An analysis of urban thermal characteristics and associated land cover in Tampa Bay and Las Vegas using Landsat satellite data. Remote Sensing of Environment 104: 147-156.

27. Zhao C, Fu G, Liu X, Fu F (2011) Urban planning indicators, morphology and climate indicators: A case study for a north-south transect of Beijing, China. Building and Environment 46: 1174-1183. 